\title{
Pathogenicity and antibiotic susceptibility of two bacterial pathogens associated with the clam Tapes decussatus in some Egyptian fisheries
}

\author{
Bahaa Abdella ${ }^{1,2}$ • Eman El-Wazzan ${ }^{2}$ • Nermeen A. El-Sersy ${ }^{3}$ • Soraya A. Sabry ${ }^{4}$ \\ Ehab R. El-Helow ${ }^{* *} \mathbb{B}$
}

${ }^{1}$ Aquatic Microbiology Department, Faculty of Aquatic and Fisheries Sciences, Kafrelsheikh University, Kafr El-Shiekh, Egypt

${ }^{2}$ Aquaculture Division, National Institute of Oceanography and Fisheries, Alexandria, Egypt

3Marine Environmental Division, National Institute of Oceanography and Fisheries, Alexandria, Egypt

${ }^{4}$ Department of Botany and Microbiology, Faculty of Science, Alexandria University, Alexandria, Egypt

*Corresponding author: elhelow@fulbrightmail.org

Received date: 30.06.2017 Accepted date: 14.09.2017

How to cite this paper:

Abdella, B., El-Wazzan E., El-Sersy, N., Sabry, S.A. \& El-Helow, E.R. (2017). Pathogenicity and antibiotic susceptibility of two bacterial pathogens associated with the clam Tapes decussatus in some Egyptian fisheries. Ege Journal of Fisheries and Aquatic Sciences, 34(4):383-389. doi: 10.12714/egejfas.2017.34.4.04

\begin{abstract}
Bivalve aquaculture is generally influenced by bacterial pathogens that cause high mortality-related losses in hatcheries. Six bacterial phenotypes had been previously isolated as the most predominant microorganisms in carpet shell clam (Tapes decussates) samples collected from natural beds in representative Egyptian clam fisheries. The main aims of this study were to investigate the nature of the pathogenic strains that significantly affect clam survival and test their susceptibility to commercially available antibiotics. Based on their $16 \mathrm{~S}$ rRNA sequences and some biochemical features, two potent clam pathogens were emerged; one of which is gram-positive and the other is gram-negative. The former isolate was identified as Micrococcus luteus and the latter as Vibrio alginolyticus. Experimental challenges with the two bacterial pathogens introduced at different initial cell concentrations $\left(2.5 \times 10^{4}-7.5 \times 10^{4}\right.$ cfu ml-1) showed markedly diverse clam mortality results. However, the pathogenic interaction of $M$. luteus with clam survival was generally higher than that of $V$. alginolyticus. When introduced at a relatively low initial cell density, the infectious records of $V$. alginolyticus were significantly increased suggesting that the expression of its key virulence factors is mainly triggered as a response to host contact. Antibiotic susceptibility tests suggested chloramphenicol and tetracycline as markedly effective agents that can be used to control the spread of these two bacterial pathogens in aquaculture applications.
\end{abstract}

Keywords: Micrococcus luteus, Vibrio alginolyticus, Tapes decussates, pathogenicity, fisheries and Aquaculture

\section{INTRODUCTION}

Bivalves are traditionally used in most of the coastal regions as food. They are rich in proteins with essential amino acids and polyunsaturated fats with significant amounts of omega-3 fatty acids required for the growth and development of the human body (livestrong.com, 1969; Dong, 2010). However, due to feeding by filtering large volumes of water, bivalves can concentrate different types of pollutants including trace metals and microorganisms and exert health risks to consumers (Collin et al., 2008; Ramos, et al., 2012; Tubiash, 1975).

Microbial diseases affecting marine cultured bivalves have been previously revised and analyzed taxonomically and phylogenetically (Paillard et al., 2004). These included Pecten larvae-Vibrio pectinicida, brown ring disease, juvenile oyster disease, Pacific oyster nocardiosis and summer mortalities of oysters.

Disease-associated mass mortalities of bivalves were responsible for declining bivalve populations in commercial clam beds and fisheries in many areas such as the Yellow Sea of Korea, China as well as in Europe (Paillard, 2004; Park, et al., 2006). Aquaculture of molluscs is greatly influenced worldwide by bacterial pathogens that cause high mortalities and losses in hatcheries as well as in natural beds. Vibrio species are considered the main bacterial pathogens being responsible for the mortality outbreaks in aquaculture over the past few years (Romalde and Barja, 2010, Chatterjee and Haldar, 2012). As well, a new bacterial pathogen identified as a Vibrio spp has been recently isolated from bivalves (Dubert et al., 2016).

Therefore, the control of bacterial diseases in aquaculture is still an active research field. It involves investigating alternative treatment and disease prevention methods such as the use of disinfectants, antibiotics and vaccines (Romero, et al., 2012). However, governmental controlling actions are required for responsible use of antimicrobial agents in commercial scales. Based on preliminary research results, it has been also suggested that probiotics enhance the immune response of fish and confer tolerance against different stressors (Dawood and Koshio, 2016).

Investigations regarding the occurrence of pathogens in bivalves and their possible effects on bivalve survival and 
production in some countries and water areas are still needed. The present work was mainly conducted to uncover some necessary microbial information related to marine bivalves collected from Egyptian commercial fisheries using the carpet shell clam, Tapes decussatus as a model.

The main aims of the present study were to identify major clam-associated bacterial pathogens and assess their potentials to cause clam mortalities in addition to their sensitivity to some commercially available antibiotics.

\section{MATERIALS AND METHODS}

\section{Test animal}

Healthy clams of Tapes decussatus were collected from natural fishery of Ismailia coast with the aid of divers. In each experiment, about two hundred clams were used. The shell lengths of clams ranged between 19.2-38.5 $(28.3 \pm 6.1) \mathrm{mm}$, whereas the whole weight range was between $1.28-10.33$ grams.

\section{Bacterial growth medium}

Bacterial isolates were kept in refrigerator on nutrient agar medium. Nutrient broth was used for cultivation of bacterial strains. Both medium was prepared by seawater instead of distilled water.

\section{Bacterial isolates and mortality assay}

Six distinct bacterial phenotypes have been previously isolated from Egyptian clam fisheries on TCBS agar plates (Abdella, et al., 2015). Bacterial isolates were purified and kept at -80 in cryo-tube. The assessment of the bacterial potential to infect clam was conducted using a modified method after Gómez-León et al., (2008). Three replicates of $4 \mathrm{~L}$ containers were used for each of the six bacterial isolates in addition to three containers as control without bacteria. Containers were filled with two liters of seawater sterilized by chlorination followed by de-chlorination (Kemp, 2006). Thirty randomly chosen clams were added to each container at room temperature. Bacterial cells were introduced with a final concentration of approximately $5 \times 10^{4} \mathrm{cfu} \mathrm{ml}^{-1}$. Clam survival was checked twice in a day and gaped or dead clams were removed and counted. The water was replaced in $50 \%$ weekly.

\section{Statistics}

All statistical analyses were conducted using Microsoft Excel 2013. The differences in survival between clam samples exposed to different concentrations of experimental pathogenic bacteria were analyzed by the one-way ANOVA test to evaluate their global significance. This was followed by LSD post-hoc test to determine the specific pairs of means that differ significantly at $\alpha=0.05$.

\section{Molecular characterization of bacterial isolates}

DNA was obtained by harvesting up to $2 \times 10^{9}$ bacterial cells in a $1.5 \mathrm{ml}$ micro-centrifuge tube by centrifugation for 10 $\mathrm{min}$ at $5000 \mathrm{x}$ g. The pellet was re-suspended in $180 \mu \mathrm{l}$ of lysis
Solution (Sigma). Proteinase K (20 $\mu$ l) was added and mixed. The mixture was incubated at $56^{\circ} \mathrm{C}$ with shaking till complete lysis (about $30 \mathrm{~min})$. RNase $\mathrm{A}(20 \mu \mathrm{l})$ was added, mixed and incubated for $10 \mathrm{~min}$ at room temperature. After centrifugation (10 min, $5000 \times \mathrm{g}$ ), clear filtrate was transferred to a new microfuge tube for ethanol precipitation. DNA was then purified using genomic DNA purification columns (GeneJET ${ }^{\mathrm{TM}}$ ). PCR reaction was performed with Maxima $\AA$ Hot Start Master Mix. The PCR components were mixed with F27 and R1492 16S rDNA universal primers and DNA template in nuclease free water (Lane, 1991). PCR was then performed using the thermal cycling of $94,94,50,72,72^{\circ} \mathrm{C}$ for $10 \mathrm{~min}, 20 \mathrm{~s}, 1 \mathrm{~min}, 1.5 \mathrm{~min}$, $10 \mathrm{~min}$ respectively. PCR product was loaded on $1 \%$ agarose gel against $1 \mathrm{~Kb}$ ladder for analysis, purified using GeneJET ${ }^{\text {TM }}$ purification column and sequenced by an $A B I 3730 x$ I DNA sequence analyzer. Homology search for the obtained sequences was performed using BLAST through NCBI. A maximum likelihood phylogenetic tree was constructed using the software Molecular Evolutionary Genetics Analysis version 7.0 (Kumar et al., 2016)

\section{Phenotypic characterization}

In addition to microscopic examination of cell morphology and gram staining, potent clam pathogens were subjected to biochemical characterization using API 20E for Gram-negative and the API STAPH for Gram-positive isolates following the manufacturing instructions (biomerieux).

\section{Antibiotic susceptibility test}

Antibiotic susceptibility test was carried out using disc diffusion method (Kayser et al., 2005; Jorgensen and Ferraro, 2009) on Muller-Hinton Agar. Sodium chloride was added to the medium (1\%) to give optimal growth for Vibrio spp. (Ottaviania et al., 2001). The antibiotics tested included Rifampicin (RD

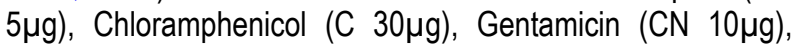

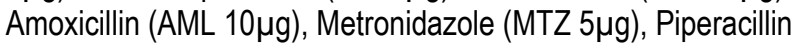

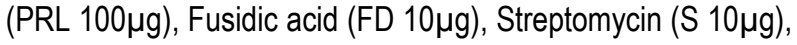

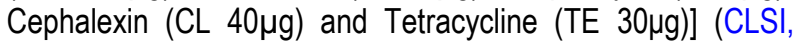
2007; Jorgensen and Ferraro, 2009; Kayser et al., 2005). Plates incubated at $37^{\circ} \mathrm{C}$ for $24 \mathrm{~h}$ and the inhibition zone diameter was measured and recorded to the nearest millimeter. Observed diameters were translated into susceptible, intermediate and resistant categories according to the inhibition zone diameter standard table of Clinical and Laboratory Standards Institute (CLSI, 2007; Jorgensen and Ferraro, 2009).

\section{RESULTS}

\section{Experimental bacterial challenges}

We evaluated the relative survival of Tapes decussatus under experimental challenges using six phenotypically distinct bacterial isolates (B1-6) that had been previously isolated as the most predominant microorganisms in some Egyptian carpet shell clam samples. After 15 days of bath exposure, considerable differences in susceptibility to bacterial challenges were observed. However, among the six examined bacterial isolates, only B4 and B6 showed significant clam 
mortality records that exceeded $50 \%$ (data not shown). Until the end of the incubation period, no mortality was detected in the control cultures.

\section{B6}

Characterization of the potent clam pathogens B4 and

After Gram staining, microscopic examination demonstrated that B4 cells are Gram-positive cocci and that B6 cells are Gram-negative and rod-shaped. PCR amplification of the DNA extracted from each of the two pathogenic isolates resulted in approximately a 1400 base pair fragment of the $16 \mathrm{~S}$ rDNA region. Based on nucleotide homology analysis of the obtained sequences, the isolates B4 and B6 have been identified as members of the species Micrococcus luteus and Vibrio alginolyticus which are well known causative agents of severe diseases such as meningitis (Altuntas et al., 2004) and vibriosis (Laganà et al., 2011), respectively. The two sequences were submitted to DNA Data Bank of Japan (DDBJ) with the accession numbers $A B 859252$ and $A B 859251$ for isolate B4 and $B 6$ respectively. The phylogenetic relationships between each of the two isolates and some closely related genotypes showed in Fig 1.
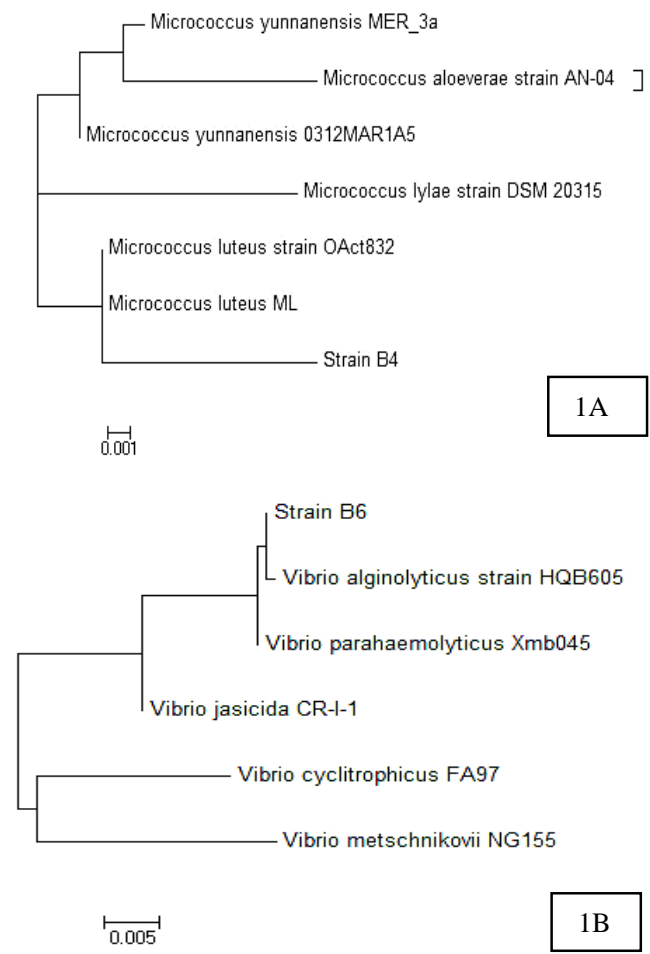

Figure 1. A maximum likelihood phylogenetic tree based on $16 \mathrm{~S}$ rDNA genes of the isolates $B 4(A)$ and $B 6(B)$ and closely related sequences. The branch lengths indicate the number of substitutions per site
The two pathogenic isolates were further subjected to biochemical tests which confirmed the molecular characterization results of B4 as a M. luteus strain and B6 as a $\mathrm{V}$. alginolyticus strain (data not shown).

Effect of $M$. luteus and $V$. alginolyticus dosages on survival of Tapes decussatus

Carpet shell clam cultures were separately exposed to three different concentrations of the experimental pathogenic strains of $M$. luteus and $V$. alginolyticus. As shown in Fig 2 and 3 , mortalities were absent or very low under unchallenged control conditions. However, all bath exposure challenges showed that $M$. luteus and $V$. alginolyticus induced considerable mortalities. The highest examined $M$. luteus cell concentration $\left(7.5 \times 10^{4}\right)$ induced $T$. decussatus mortalities up to more than $50 \%$ death after 17 days of exposure and $100 \%$ in the $18^{\text {th }}$ day (Fig 2). Lower mortality records were observed with the lower concentrations $\left(2.5 \times 10^{4}\right.$ and $\left.5.0 \times 10^{4}\right)$. On the other hand, the lowest examined level of $V$. alginolyticus cells $\left(2.5 \times 10^{4}\right)$ appeared to be the most effective dose as it induced the highest $T$. decussatus mortality records (more than 30\%) within 17 days of exposure (Fig 3). The number of dead clams was then continued to increase to reach $45 \%$ within 39 days. On the other hand, lower mortality records were observed in the presence of higher bacterial cell concentrations.

The one-way ANOVA test revealed that there are significant variations among the observed mortality records (Table 1 ) with $\mathrm{P}=0.00818$ for $M$. luteus and $\mathrm{P}=0.000283$ for $\mathrm{V}$. alginolyticus. Performing post-hoc tests and plotting the means of number of dead clams against concentration of bacteria (Fig 4) confirmed that the challenging effects caused by the highest examined $M$. luteus dose and the lowest introduced $V$. alginolyticus level on clams are significant.

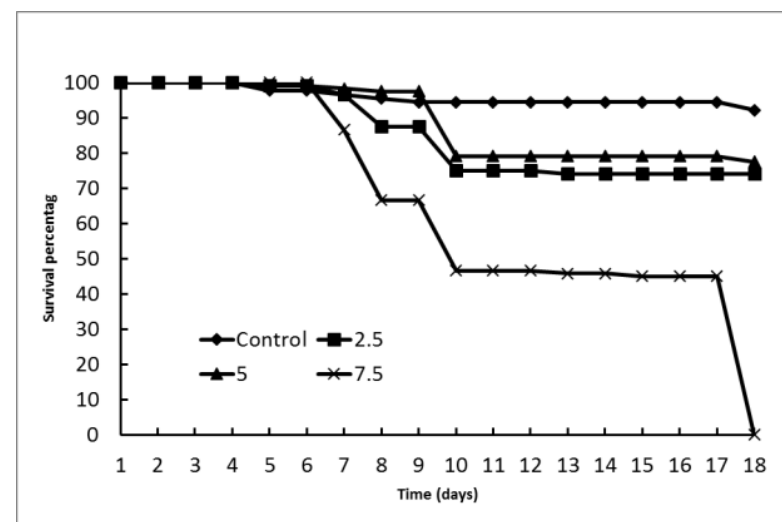

Figure 2. Survival percentage of $T$. decussatus challenged with three different concentrations of $M$. luteus (conc. $1=2.5 \times 10^{4}$, conc. $2=5 \mathrm{X}$ $10^{4}$ and conc. $3=7.5 \times 10^{4} \mathrm{cfu} \mathrm{ml}^{-1}$ ) 


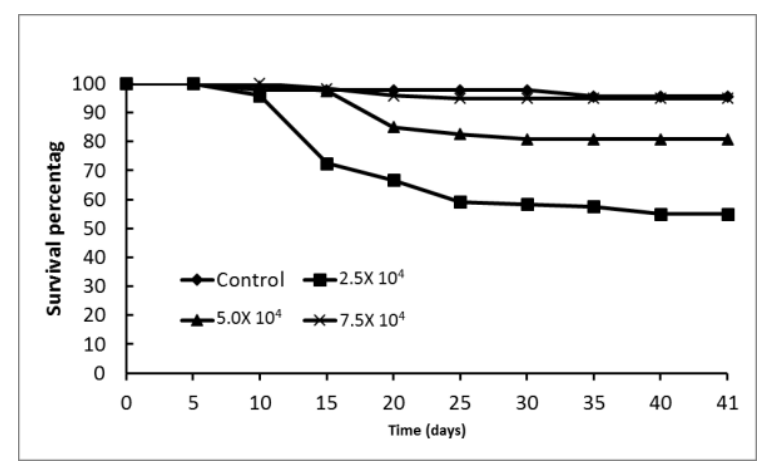

Figure 3. Survival percentage of $T$. decussatus challenged with three different concentrations of $V$. alginolyticus $\left(2.5 \times 10^{4}, 5 \times 10^{4}\right.$ and 7.5 $X 10^{4} \mathrm{cfu} \mathrm{ml}^{-1}$ )

Table 1. ANOVA test for the effect of different bacterial cell concentrations of $M$. luteus and $V$. alginolyticus on $T$. decussatus mortalities

\begin{tabular}{lccccc}
\hline Organism & SS & df & MS & F & P-value \\
\hline M. luteus & 1757.167 & 3 & 585.7222 & 6.60025 & 0.00818 \\
\hline V. alginolyticus & 371.5167 & 3 & 123.8389 & 15.58316 & 0.000283
\end{tabular}

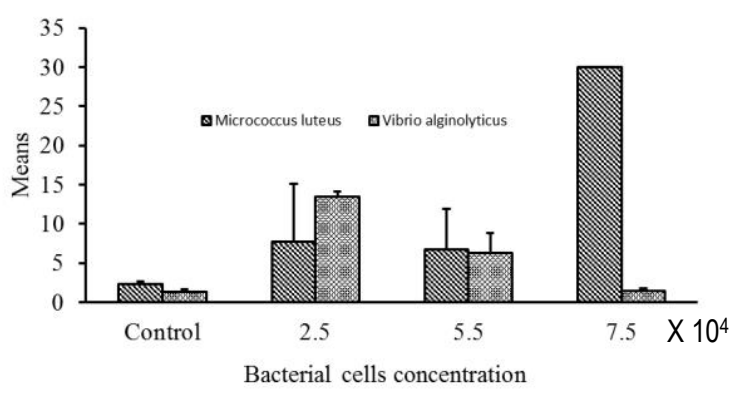

Figure 4. Means of dead T. decussatus as a response to exposure to different bacterial concentrations

\section{Screening for antibacterial susceptibility}

Intensive aquaculture applications lead to the spread of several bacterial pathogens, which in turn necessitate the use antimicrobials. In the present work, the experimental $M$. luteus and $V$. alginolyticus isolates were assayed for their susceptibility to ten different antibiotics currently used in aquaculture practices. Based on the inhibition zone diameters shown in Fig 5, the phenotypes of B4 and B6 can be described as sensitive, intermediate or resistant to an antibiotic. The results indicated that $M$. luteus and V. alginolyticus isolates respond similarly with most antibiotics; for instance, both are resistant to metronidazole and fusidic acid and highly sensitive to chloramphenicol and tetracycline. However, the effects of gentamicin, piperacillin, streptomycin and cephalexin on the two pathogens are relatively intermediate. On the other hand, the two isolates responded oppositely to rifampicin and amoxicillin where the former was not effective against $M$. luteus and the later was resisted by $V$. alginolyticus.

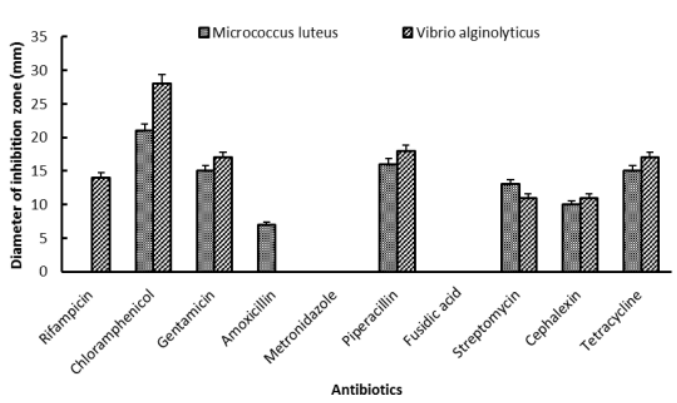

Figure 5. Inhibition zone diameters expressed in $\mathrm{mm}$ corresponding to ten antibiotics against $M$. luteus and V. Alginolyticus

\section{DISCUSSION}

In the present study, two microbial pathogenic strains that significantly affect clam survival have been isolated and identified as members of the gram-positive species $M$. luteus (B4) and the gram-negative species $V$. alginlyticus (B6). These results support the findings reported by other workers who suggested the ability of these two-bacterial species to cause disease and induce mortality in bivalves (Wu et al., 2013). They examined the ability of $M$. luteus and $V$. anguillarum to induce an immunological response in the mussel Mytilus galloprovincialis such as osmotic stress, disturbance in energy metabolism and alteration of metabolic biomarkers. They found that both of these two bacteria are able to induce osmotic regulation disturbances, oxidative stress, cellular injury but with different levels of severity in mussels.

Many Micrococcus spp. and closely related genera are generally harmless saprophytes. However, M. luteus can infect different hosts including humans, mammals, and some marine animals such as fish, sharks, crustacean shellfish, shrimps, and prawns (PHAC, 2011). M. luteus has been reported as a causative agent in cases of meningitis, intracranial abscesses, pneumonia and septic arthritis in immune-suppressed or immune-competent persons (Altuntas et al., 2004; PHAC, 2011). The study conducted by Aydın et al. (2005) also confirmed that $M$. luteus must be considered as a potential bacterial pathogen for fish.

The cell wall teichuronic acid (TUA) of $M$. luteus is an acidic long-chain polysaccharide polymer and has some similarity with that of the so-called capsular polysaccharides which are usually considered to be essential and virulent factors for pathogenic bacteria, such as Streptococca and Staphylococca (Deng et al., 2010). Therefore, the more the doze of M. luteus cells faced by the host, the more their infectious severity. 
The second isolated pathogenic bacterium, V. alginolyticus has been reported as a causative agent of vibriosis which is the most commonly encountered disease associated with intensive bivalve cultures in hatcheries and nurseries (Miossec et al., 2009). In the South China Sea, V. alginolyticus was reported to be the dominant causative agent of high mortality vibriosis in the large yellow croaker, sea bream, grouper, kuruma prawn and shellfish species (Liu et al., 2004). V. alginolyticus reported to be common in adult bivalve over the bivalve in the hatcheries (Wang et al., 2016). Besides, it was reported that other vibrios such as Vibrio europaeus cause mortality in larvae of other kinds of clams (Dubert et al. 2017).

In contrast to the case of $M$. luteus, our results demonstrated that the clam mortality caused by the $V$. alginolyticus isolate is inversely proportional to initial challenge concentrations of the cells. A similar observation has been previously reported with respect to susceptibility of cod yolk-sac larvae to different concentrations of Vibrio spp (Sandlund et al., 2010). They found that the larvae challenged with relatively low doses $\left(10^{4}\right.$ cfu $\mathrm{ml}^{-1}$ ) suffered mortality significantly more than those infected by higher bacterial cell densities. This unpredicted mortality impact of the relatively low bacterial doses observed in the present work could be explained as a consequence of host and/or pathogen behavior and interaction. With respect to the host, it has been reported that bivalves have the ability to regulate ingestion of particles present at high concentrations by rejecting the excess as pseudofaeces (Arapov et al., 2010). Concerning the bacterial pathogen, it can be speculated that the community of Vibrio cells developed on the host as a growth environment is more physiologically adapted as pathogens when compared to seed culture cells grown on the experimental growth medium.

Moreover, the metabolic and behavioral activities of a bacterial community is affected by quorum sensing; a cell-to-cell bacterial communication which involves intercellular signaling mechanisms in response to cell density (Sifri, 2008). It is also known that most bacterial cells have a remarkable ability to adapt to enormously diverse environmental conditions. Pathogenic bacteria, for example, have to cope with adverse conditions, such as the host environment and host defense reactions. This normally takes place by triggering alternative metabolic and energy generation pathways in bacterial cells (Kidd, 2011).

Another considerable issue is that pathogens have to induce complex regulatory networks that ensure adequate expression of their virulence genes (Duprey et al., 2014). This is mainly because many virulence factors are costly metabolic products and their production is under strict regulatory control mechanisms including quorum sensing (Ruwandeepika et al. 2012). For instance, the alkaline serine protease was shown to be a virulence factor of $V$. alginolyticus and its expression takes place at late growth stages to reduce the possibility of effective host defenses (Rui et al., 2009). As well, the development of capsule is involved in attachment of the vibrios to the host cells (Hsieh et al., 2003) and plays an important role in immune avoidance (Chen et al., 2010). Therefore, it can be concluded that expression of key virulence factors in $V$. alginolyticus is not constitutive but rather depends on regulatory mechanisms controlled by bacterial cell-density as well as the nature of the host as a growth environment. Thereby, infection of the clam body with few numbers of $V$. alginolyticus cells may allow a chance for a lag adaptation phase followed by generating a huge number of bacterial cells that have evolved with specialized metabolic regulations customized for interaction with the host environment. On the contrary, invasion of the clam with a large number of Vibrio cells that are not pre-adapted to operate with the host body as a growth environment would not be as much effective.

From genomic point of view, a study conducted by Castillo et al. (2015) who worked on two draft genomes of $V$. alginolyticus has identified different virulence factors that could be related to pathogenicity. They have succeeded by using computational approach in the detection of the genes that encodes virulence factors such as collagenases, proteases, and hemolysin), and toxins (RTX, YafQ).

Intensive aquaculture applications have promoted the growth of several bacterial diseases and consequently increased the need for appropriate microbial control methods (Carvalho et al., 2012; Romero et al., 2012). Vaccination was suggested as an ideal method for preventing infectious diseases in the aquaculture field (Deep et al., 2011). However, many aquaculture vaccines are predicted to prompt the evolution of more virulent strains because of being developed for preventing disease symptoms and mortality rather than avoiding infection and transmission (Kennedy et al., 2016). Therefore, it is still necessary to consider chemotherapeutic agents as effective tools against bacterial infections in aquaculture practices.

The results of antibiotic sensitivity test carried out in this work showed that the two experimental $M$. luteus and $V$. alginolyticus isolates are highly sensitive to chloramphenicol, and tetracycline which are protein synthesis inhibitors. In addition, the $V$. alginolyticus isolate was also sensitive to gentamicin which interferes with protein synthesis as well. Similar sensitivity results have been reported for M. luteus (Fazlani et al., 2011) and V. alginolyticus isolates (Mustapha et al., 2013). However, the use of such chemotherapeutics in aquacultures must be controlled by government agencies, particularly with respect to dose rates and limitations.

\section{ACKNOWLEDGEMENT}

The authors would like to thank the Science and Technology Development fund for funding this research as part of the US-Egypt project \# 1971 entitled "Biomarker Assisted Selection for Disease-Resistance in Clams for Establishing Egyptian and Improving American Bivalve Aquaculture" (20102014). 


\section{REFERENCES}

Abdella, B., El-Wazzan E., El-Sersy, N.A., El-Helow, E.R. \& Sabry, S.A, (2015). Dynamics of bacterial pathogens associated with the clam Tapes decussatus in three main Egyptian fisheries. Journal of Advances in Biology, 8(2):1614-1622.

Altuntas, F., Yildiz, O., Eser, B., Gündogan, K., Sumerkan, B. \& Çetin, M. (2004). Catheter-related bacteremia due to Kocuria rosea in a patient undergoing peripheral blood stem cell transplantation. BioMedical Central Infectious, 4(1):62. doi: 10.1186/1471-2334-4-62

Arapov, J., Ezgeta-Balić, D., Peharda, M. \& Ninčević Gladan, Ž. (2010). Bivalve feeding- how and what they eat? Croatian Journal of Fisheries, 68(3):105116.

Aydin, S., Ciltas, A., Yetim, H. \& Akyurt, I. (2005). Clinical, pathological and haematological effects of Micrococcus luteus infections in Rainbow Trout (Oncorhynchus mykiss Walbaum). Journal of Animal and Veterinary Advances, 4(2):167-174.

Carvalho, E.D., David, G.S. \& Silva, R.J. (Eds.). (2012). Health and Environment in Aquaculture. Rijeka, Croatia: InTech. doi: 10.5772/2462

Castillo, D., D’Alvise, P., Kalatzis, P. G., Kokkari, C., Middelboe, M., Gram, L. Liu, S. \& Katharios, P. (2015). Draft genome sequences of Vibrio alginolyticus strains V1 and V2, opportunistic marine pathogens. Genome Announcements. 3(4):e00729-15. doi: 10.1128/genomeA.00729-15

Chatterjee, S. \& Haldar, S. (2012). Vibrio related diseases in aquaculture and development of rapid and accurate identification methods. Journal of Marine Science: Research \& Development, 1(2):1-7 doi: 10.4172/2155-9910.S1-002

Chen, Y., Dai, J., Morris, J.G. Jr. \& Johnson, J.A., (2010). Genetic analysis of the capsule polysaccharide ( $\mathrm{K}$ antigen) and exopolysaccharide genes in pandemic Vibrio parahaemolyticus 03:K6. BMC Microbiology 10:274. doi: 10.1186/1471-2180-10-274

CLSI. (2007). Performance Standards for Antimicrobial. Susceptibility Testing; Seventeenth. Informational Supplement. Pennsylvania, USA: Clinical and Laboratory Standards Institute (CLSI).

Collin, B., Rehnstam-Holm, A. \& Hernroth, B. (2008). Faecal contaminants in edible bivalves from Maputo Bay, Mozambique: Seasonal distribution, pathogenesis and antibiotic resistance. The Open Nutrition Journal, 2:8693. doi: $10.2174 / 1874288200802010086$

Dawood, M. A. \& Koshio, S. (2016). Recent advances in the role of probiotics and prebiotics in carp aquaculture: A review. Aquaculture, 454:243-251. doi: $10.1016 /$ j.aquaculture.2015.12.033

Deep, A., Chaudhary, U. \& Gupta, V., (2011). Quorum sensing and Bacteria Pathogenicity: From Molecules to Disease. Journal of Laboratory Physicians.; 3(1):4-11. doi: 10.4103/0974-2727.78553

Deng, L.L., Alexander, A. A., Lei, S. \& Anderson, J.S. (2010). The cell wall teichuronic acid synthetase (tuas) is an enzyme complex located in the cytoplasmic membrane of Micrococcus luteus. Biochemistry Research International, 2010:1-8. doi: 10.1155/2010/395758

Dubert, J., Romalde, J.L., Prado, S. \& Barja, J.L. (2016). Vibrio bivalvicida sp. nov., a novel larval pathogen for bivalve molluscs reared in a hatchery. Systematic and Applied Microbiology, 39(1):8-13. doi: 10.1016/j.syapm.2015.10.006

Dubert, J., Aranda-Burgos, J.A., Ojea, J., Barja, J.L. \& Prado, S. (2017) Mortality event involving larvae of the carpet shell clam Ruditapes decussatus in a hatchery: isolation of the pathogen Vibrio tubiashii subsp. Europaeus Journal of Fish Diseases 40:1185-1193. doi: $10.1111 /$ jfd.12593
Dong, F.M. (Ed.). (2010). The Nutritional Value of Shellfish. Washington, USA: A Washington Sea Grant publication.

Duprey, A., Reverchon, S. \& Nasser, W. (2014). Bacterial virulence and Fis: adapting regulatory networks to the host environment. Trends in Microbiology, 22(2):92-99. doi: 10.1016/j.tim.2013.11.008

Fazlani, S.A., Khan, S.A., Faraz, S. \& Awan, M.S. (2011). Antimicrobia susceptibility of bacterial species identified from mastitic milk samples of camel. African Journal of Biotechnology,10(15):2959-2964 doi: $10.5897 / A J B 10.716$

Gómez-León, J., Villamil, L., Salger, S. A., Sallum, R.H., Remacha-Triviño, A. Leavitt, D.F. \& Gómez-Chiarri, M. (2008). Survival of eastern oysters Crassostrea virginica from three lines following experimental challenge with bacterial pathogens. Diseases of Aquatic Organisms, 79:95-105. doi: $10.3354 /$ dao01902

Hsieh, Y.C., Liang, S.M., Tsai, W.L., Chen, Y.H., Liu, T.Y. \& Liang, C.M., (2003). Study of capsular polysaccharide from Vibrio parahaemolyticus. Infection and Immunity, 71:3329-3336. doi: 10.1128/IAI.71.6.3329-3336.2003

Jorgensen, J.H. \& Ferraro, M.J. (2009). Antimicrobial susceptibility testing: A review of general principles and contemporary practices. Clinical Infectious Diseases, 49(11):1749-1755. doi: 10.1086/647952

Kayser, F.H., Bienz, K.A., Eckert, J. \& Zinkernagel, R.M. (Eds.). (2005). Medical Microbiology. New York, USA: Thieme Stuttgart.

Kemp, P.S. (Ed.). (2006). Oyster Hatchery Manual. North Carolina, USA: Carteret Community College.

Kennedy, D.A., Kurath, G., Brito, I.L., Purcell, M.K., Read, A.F., Winton, J.R. \& Wargo, A.R. (2016). Potential drivers of virulence evolution in aquaculture. Evolutionary Applications, 9(2):344-354. doi: 10.1111/eva.12342

Kidd, S. P. (Ed.). (2011). Stress Response in Pathogenic Bacteria. Wallingford, Oxfordshire, UK: CAB International. doi: $10.1079 / 9781845937607.0093$

Kumar, S., Stecher G. \& Tamura, K. (2016). MEGA7: Molecular Evolutionary Genetics Analysis version 7.0 for bigger datasets. Molecular Biology and Evolution, 33:1870-1874. doi: 10.1093/molbev/msw054

Laganà, P., Caruso, G., Minutoli, E., Zaccone, R. \& Delia, S. (2011). Susceptibility to antibiotics of Vibrio spp. and Photobacterium damsela ssp. piscicida strains isolated from Italian aquaculture farms. New Microbiologica, 34(1):53-63.

Lane, D. (1991). 16S/23S rRNA Sequencing. In Stackebrandt, E. \& Goodfellow, M. (Eds.), Nucleic Acid Techniques in Bacterial Systematics (115-175). New York, USA: John Wiley \& Sons.

Livestrong.com, (1969) 5 Things You Need to Know About the Health Benefits of Clams. Retrieved from LIVESTRONG.COM: http://www.livestrong.com/article/5384-need-health-benefits-clams/ (05.05.2013)

Liu, C.H., Cheng, W., Hsu, J.P. \& Chen, J.C. (2004). Vibrio alginolyticus infection in the white shrimp Litopenaeus vannamei confirmed by polymerase chain reaction and 16S rDNA sequencing. Diseases of aquatic organisms, 61(1-2):169-174. doi: 10.3354/dao061169

Miossec, L., Le Deuff, R.M. \& Goulletquer, P. (2009). Alien species alert: Crassostrea gigas (Pacific oyster). ICES Cooperative Research Report, 299

Mustapha, S., Mustapha, E. M. \& Nozha, C. (2013). Vibrio alginolyticus: an emerging pathogen of food borne diseases. International Journal of Science and Technology, 2(4):302-309. 
Ottaviania, D., Bacchiocchi, I., Masini, L., Leoni, F., Carraturo, A., Giammarioli, M. \& Sbaraglia, G. (2001). Antimicrobial susceptibility of potentially pathogenic halophilic vibrios isolated from seafood. International Journal of Antimicrobial Agents, 18(2):135-140. doi: 10.1016/S0924-8579(01)00358-2

Paillard, C. (2004). A short-review of brown ring disease, a vibrosis affecting clams, Ruditapes philippinarum and Ruditapes deccusatus. Aquatic Living Resources, 17:467-475. doi: 10.1051/alr:2004053

Paillard, C., Roux, F. \& Borrego, J.J. (2004). Bacterial disease in marine bivalves a review of recent studies: trends and evolution. Aquatic Living Resources, 17:477-498. doi: 10.1051/alr:2004054

Park, K., Paillard, C., Le Chevalier, P. \& Choi, K. (2006). Report on the occurrence of brown ring disease (BRD) in manila clam, Ruditapes philippinarum on the west coast of Korea. Aquaculture, 255(1-2):610-613. doi: 10.1016/j.aquaculture.2005.12.011

PHAC- (2011). Micrococcus spp. Public Health Agency of Canada. Retrieved from http://www.phac-aspc.gc.ca/lab-bio/res/psds-ftss/micrococcuseng.php (24.10.2013)

Ramos, R.J., Pereira, M.A., Miotto, L.A., Faria, R.D., Junior, N.S. \& Vieira, C. R. (2012). Ocurrence of Vibrio spp., positive coagulase staphylococci and enteric bacteria in oysters (Crassostrea gigas) harvested in the south bay of Santa Catarina island, Brazil. Ciência e Tecnologia de Alimentos, 32(3):478-484. doi: 10.1590/S0101-20612012005000061

Romalde, J. \& Barja, J. (2010). Bacteria in molluscs: good and bad guys. Formatex, 136-147.

Romero, J.M., Feijoó, C.G. \& Navarrete Wallace, P.A. (2012). Antibiotics in aquaculture use, abuse and alternatives; In: Carvalho, E.D., David, J.S. \& Silva, R.J. (Eds.), Health and Environment in Aquaculture, p. 159. doi: $10.5772 / 28157$
Rui, H., Liu, Q., Wang, Q., Ma, Y., Liu, H., Shi, C. \& Zhang, Y. (2009). Role of alkaline serine protease, asp, in Vibrio alginolyticus virulence and regulation of its expression by luxO-luxR regulatory system. J Microbiol Biotechnol, 19:431-438. doi: 10.4014/jmb.0807.404

Ruwandeepika, D., Arachchige, H., Sanjeewa Prasad Jayaweera, T., Paban Bhowmick, P., Karunasagar, I., Bossier, P. \& Defoirdt, T. (2012). Pathogenesis, virulence factors and virulence regulation of vibrios belonging to the Harveyi clade. Reviews in Aquaculture, 4(2):59-74 doi: 10.1111/j.1753-5131.2012.01061.x

Sandlund, N., Rødseth, O.M., Knappskog, D.H., Fiksdal, I.U. \& Bergh, Ø. (2010). Comparative susceptibility of turbot, halibut, and cod yolk-sac larvae to challenge with Vibrio spp. Diseases of Aquatic Organisms, 89: 29-37. doi: $10.3354 /$ da002176

Sifri, C. D. (2008). Quorum Sensing: Bacteria Talk Sense. Clinical Infectious Diseases, 47(8):1070-1076. doi: 10.1086/592072

Tubiash, H.S. (1975). Bacterial pathogens associated with cultured bivalve mollusk larvae. In W. L. Smith, \& M. H. Chanley (Eds.), Culture of Marine Invertebrate Animals (61-71). New York, USA: Springer. doi: 10.1007/978-1-4615-8714-9_4

Wang, Z., Wang, B., Chen, G., Jian, J., Lu, Y., Xu, Y. \& Wu, Z. (2016). Transcriptome analysis of the pearl oyster (Pinctada fucata) hemocytes in response to Vibrio alginolyticus infection. Gene 575:421-428. doi: 10.1016/j.gene.2015.09.014

Wu, H., Ji, C., Wei, L., Zhao, J. \& Lu, H. (2013). Proteomic and metabolomic responses in hepatopancreas of Mytilus galloprovincialis challenged by Micrococcus luteus and Vibrio anguillarum. Journal of Proteomics, 94(6): 54-67. doi: 10.1016/j.jprot.2013.09.001 